\title{
Relationship between soil properties and potentially toxic element content based on the dataset of the Soil Information and Monitoring System in Hungary
}

\author{
Szilveszter Csorba ${ }^{1}$, Judit Berényi Üveges ${ }^{1}$, András Makó ${ }^{2}$ \\ ${ }^{I}$ National Food Chain Safety Office, Budapest, Hungary \\ ${ }^{2}$ Institute for Soil Sciences and Agricultural Chemistry, Centre for Agricultural Research, Hungarian \\ Academy of Sciences, Budapest, Hungary
}

\begin{abstract}
The aim of this paper is to examine the relationship between soil properties and potentially toxic element contents of arable soils based on the dataset of the Soil Information and Monitoring System in Hungary. Nine potentially toxic elements ( $\mathrm{As}, \mathrm{B}, \mathrm{Cd}, \mathrm{Co}, \mathrm{Cr}, \mathrm{Cu}, \mathrm{Ni}, \mathrm{Pb}, \mathrm{Zn}$ ) were compared with selected soil parameters. We carried out grouping of related soil properties by principal component analysis. The method was suitable to describe the relationship within groups of the soil properties. We studied correlations of the resulting components and potentially toxic elements. The change of Ni content was influenced by the physical properties of the soil (e.g. clay content, field capacity, $\mathrm{R}=0.67$ ). Boron is the only one of the examined elements that indicates significant positive correlation with saline-alkali $(\mathrm{R}=0.21)$ parameters. $\mathrm{Zn}, \mathrm{Co}$ and $\mathrm{Cr}$ behaved very similarly; their correlation with components 1 and 2 were the closest.
\end{abstract}

Key words: principal component analyses (PCA), Soil Information and Monitoring System (SIMS), soil properties, potentially toxic elements (PTE), Pearson correlation

\section{Introduction}

Soils may vary considerably according to their chemical, physical and biological characteristics. Thus, metal solubility and extractability may be affected by the total metal contents or by simultaneous variation in soil properties $(\mathrm{pH}, \mathrm{CEC}$, organic matter, mineral composition, and soil texture) (Hlavay et al. 2004). The elements are pres-

\footnotetext{
* Corresponding author; Budaörsi u. 141-147, H-1147 Budapest, Hungary; E-mail: csorbasz@nebih.gov.hu

Received: October 28, 2014; accepted: October 28, 2014
} 
ent in soils in various forms and these can strongly affect their behavior in terms of biological availability, potential toxicity and mobility within the profile (Alloway 1995).

In the case of most cation metals the retention capacity of soil for trace metals increases with $\mathrm{pH}$ value, while other metals indicate maximum value in the neutral domains (for example: B), and yet the adsorption of most anion metals decreases with the growth of $\mathrm{pH}$ value (Adriano 2001).

A significant amount of the toxic metal content in natural and uncontaminated soil is inherited from the soil parent material (Csathó 1994). According to Kádár (1995) we considered potentially toxic elements which have a deleterious effect on the soilplants-animal-human system. Adsorption of potentially toxic elements (PTEs) in the soil occurs bydifferent methods for each element; thus the mobile contaminants of the soil (e.g. $\mathrm{Cd}, \mathrm{Zn}, \mathrm{Pb}, \mathrm{Cu}$ ) and the elements rapidly becoming insoluble $(\mathrm{Cr})$ can be distinguished (Fodor 2000).

Based on the assessments of Fügedi et al. (2006) there is no characteristic element group in most parts of Hungary (this statement refers mostly to the lowland areas of Hungary). Practically all examined elements accumulate and leach out jointly, depending on local sedimentological, pedological and agricultural factors.

The fate and transfer of metals are complex and depend on the soil's mineralogy and the physical transport processes involved (Navarro et al. 2008).

In this study we analyzed the relationship between the pseudo total PTE contents and soil property scores derived from soil parameters performing principal component analyses (PCA).

\section{Analytical method}

\section{Data source}

Data of the Hungarian Soil Information and Monitoring System (SIMS) was used for statistical analyses. This system was created in 1992 and provides yearly data regarding the condition of the Hungarian soils. Soil samples are annually taken for analyses between $15^{\text {th }}$ September and $15^{\text {th }}$ October. The nation-wide monitoring system contains 1235 sampling points. From the 1235 points 864 can be found on arable land (Juhász 2006). To get the information on baseline conditions, all the chemical, physical and biological soil parameters were determined for each horizon in the laboratory. We evaluated soil data of 842 sampling points from the top soil on arable land. We used the data of 2010 for the evaluation of descriptive statistics, and the data of 1992 for the evaluation of principal component analysis.

Laboratory methods of the used soil parameters

Pseudo total content of the potentially toxic elements was determined by digestion with a mixture of cc. nitric acid and hydrogen peroxide at $105^{\circ} \mathrm{C}$ and measured with an ICP device from the filtrate by the emissive spectrometric method (MSZ 21470-50: 1998). Characteristic basic properties of the soils were measured according the Hun- 
garian standards. The upper limit of plasticity, according to Arany (KA) was determined by mechanical mixing (MSZ 08-0205:1978). Soil texture determination was performed by the pipette method (MSZ 08-0205:1978). The water retention measurements were performed with distilled water according to the MSZ and the ISO standards (MSZ 08-0205:1978; ISO 11274:2009). The total water capacity (pF 0), the field capacity ( $\mathrm{pF} 2.5$ ) and the wilting point ( $\mathrm{pF} 4.2$ ) were determined on undisturbed soil samples. At $\mathrm{pF}$ values of 0 to $2.5,100 \mathrm{~cm}^{3}$ of water-saturated soil core samples were exposed to suction in boxes containing sand and kaolin plates. $\mathrm{pF} 4.2$ values were determined on re-saturated soil pastes in a pressure membrane apparatus with cellophane membranes. The $\mathrm{pF} 6.2$ values were calculated from hygroscopic measurements applying a relative humidity of $34 \%$ above the samples (using $\mathrm{CaCl}_{2} .6 \mathrm{H}_{2} \mathrm{O}$ as humidity regulator) (Várallyay 1973). Bulk density was calculated from dry soil weights $\left(105^{\circ} \mathrm{C}, 48 \mathrm{~h}\right)$ of undisturbed samples. $\mathrm{Ca}\left(\mathrm{CH}_{3}-\mathrm{COO}\right)_{2}$-extractable acidity (y1) and $\mathrm{KCl}$ extractable acidity (y2) was calculated from the acidimetric titration (Buzás 1993). Calcium carbonate content was determined with the Scheibler method (Nelson 1982). Organic matter content was determined by wet combustion with the Tyurin titrimetric method (Tyurin 1931). Soil $\mathrm{pH}$ was determined in 1:2.5 soil/distilled water and soil/ $\mathrm{KCl}$ suspensions using the potentiometric method (McLean 1982). Cation exchange capacity (CEC) and exchangeable $\mathrm{Ca}^{2+}, \mathrm{Mg}^{2+}$ determinations were performed with the modified Mehlich method (Buzás 1993). Total soluble salt content was calculated based on the measured electric conductivity of the saturated soil paste. Soda-alkalinity was determined in salt-affected soils measuring the phenolphthalein alkalinity (Buzás 1993).

\section{Statistical analysis of data}

Two datasets were used for statistical analysis. The most recent data are available from 2010 for the descriptive statistical analysis and we used the 1992 datasets for PCA, because the physical properties of the soil were tested only in the initial year.

We examined all those possible soil parameter effects which, based on previous experience, could influence the transport processes in the soil. The following soil properties were examined for the PCA: $\mathrm{pH}\left(\mathrm{H}_{2} \mathrm{O}\right), \mathrm{pH}(\mathrm{KCl})$, cation exchange capacity $(\mathrm{CEC}$, meq/100 g), soil organic matter (OM, \%), soil texture (clay, silt, sand, \%), Arany-type texture index (KA), bulk density $\left(\mathrm{BD}, \mathrm{g} / \mathrm{cm}^{3}\right)$, saturated water retention value $[\mathrm{pF} 0$, $\log (\mathrm{cm})]$, field capacity value $[\mathrm{pF} 2.5, \log (\mathrm{cm})]$ and wilting point $[\mathrm{pF} 4.2, \log (\mathrm{cm})]$, exchangeable $\mathrm{Ca}^{2+}, \mathrm{Mg}^{2+}(\mathrm{m} / \mathrm{V}, \%)$, total salt content (TSC, \%), soda-alkalinity (S, \%), hydrolytic acidity (y1), exchangeable acidity (y2). The following PTEs were involved in the statistical analyses: $\mathrm{Cd}, \mathrm{Cu}, \mathrm{As}, \mathrm{Ni}, \mathrm{Co}, \mathrm{Cr}, \mathrm{B}, \mathrm{Zn}$, and $\mathrm{Pb}$.

SPSS 17.0 for Windows was used for statistical analyses. The PTEs were analyzed first with descriptive statistics. Thereafter we performed the adequacy test of the soil properties for PCA. The adequacy test consists of four main parts. In the first one a correlation matrix was used to identify a possible relationship among the soil properties. The second test was the anti-image process in which the variance of the variables was 
split into an explained (image) and unexplained (anti-image) one (see 'Results and discussion'). The third test was the Barlett test which investigates the hypothesis that the variables do not correlate with each other. The fourth test was the Kaiser-MeyerOlkin (KMO) criterion, one of the most important measuring methods to decide the suitability of variables for PCA (Sajtos and Mitev 2007).Variances of the first five components were more than 1 which were used for later examinations. Thus, these components met the criteria based on Kaiser Normalization (Sajtos and Mitev 2007). Finally we studied the relationship between the received components (scores) and the PTEs with Pearson correlation.

\section{Results and discussion}

Descriptive statistics of examined PTE's content

We compared values of the examined metal and metalloid content by their basic statistic indicators (Table 1).

Table 1

Pseudo total metal content of soil samples $\left(\mathrm{mg} \mathrm{kg}^{-1}, \mathrm{n}=842,2010\right)$

\begin{tabular}{lccccccccc}
\hline $\begin{array}{l}\text { Statistical } \\
\text { indicators }\end{array}$ & As & $\mathrm{B}$ & $\mathrm{Zn}$ & $\mathrm{Cd}$ & $\mathrm{Co}$ & $\mathrm{Cr}$ & $\mathrm{Ni}$ & $\mathrm{Cu}$ & $\mathrm{Pb}$ \\
\hline Mean & 6.7 & 6.47 & 54 & 0.23 & 9.07 & 29.1 & 22.8 & 17 & 17.8 \\
Lower bound* & 6.46 & 6.14 & 52.5 & 0.21 & 8.8 & 28.3 & 22 & 16.2 & 17 \\
Upper bound* & 6.93 & 6.8 & 55.5 & 0.24 & 9.34 & 30 & 23.5 & 17.8 & 18.6 \\
5\% Trimmed & 6.47 & 6.27 & 53 & 0.21 & 9.01 & 28.6 & 22.5 & 16.7 & 17.1 \\
$\quad$ mean & & & & & & & & & \\
Median & 6.4 & 5.84 & 53.3 & 0.2 & 8.92 & 28.3 & 22.3 & 15.2 & 17.5 \\
Std. D. & 3.5 & 4.88 & 22.2 & 0.24 & 3.98 & 13.1 & 10.2 & 11.4 & 11.8 \\
Minimum & 0.29 & 0.5 & 7.25 & 0.1 & 0.9 & 3.27 & 1.95 & 0.23 & 0.99 \\
Maximum & 52.3 & 57 & 208 & 5.55 & 24.3 & 90.1 & 67.6 & 115 & 92.3 \\
CV\% & 52.3 & 75.4 & 41 & 105 & 43.9 & 44.8 & 44.9 & 67.1 & 63.4 \\
Skewness & 3.22 & 3.08 & 1.21 & 13.3 & 0.24 & 0.67 & 0.49 & 2.81 & 1.18 \\
\hline
\end{tabular}

Note: * marked means the $95 \%$ confidence interval for mean

Looking at the means and the $5 \%$ trimmed mean of the elements we can see that in each case values of the $5 \%$ trimmed mean are less than the arithmetic mean. Furthermore it can also be seen that between the maximum values and upper bound values the difference is greater than between minimum values and lower bound values. The above findings demonstrate that outliers are in the top $2.5 \%$ of the distribution. This may be caused by the influence of human activities or be of geologic origin (e.g. high arsenic content of the peat soils in Hungary). The interval between the lower and upper bound is considered to be the characteristic domain. We compared the characteristic domain and 5\% trimmed mean of the PTEs with limit values of the geologic background concentration ("A") of the 6/2009 KvVM-EüM-FVM ministerial joint decree. 
Among the examined elements $\mathrm{Cr}\left(30 \mathrm{mg} \cdot \mathrm{kg}^{-1}\right)$ and $\mathrm{Ni}\left(25 \mathrm{mg} \cdot \mathrm{kg}^{-1}\right)$ approached the limit values, followed by $\mathrm{Pb}\left(25 \mathrm{mg} \cdot \mathrm{kg}^{-1}\right)$. The lowest concentration compared to the limit value was measured in $\mathrm{Cd}\left(0.5 \mathrm{mg} \cdot \mathrm{kg}^{-1}\right), \mathrm{Zn}\left(100 \mathrm{mg} \cdot \mathrm{kg}^{-1}\right)$ and $\mathrm{Cu}\left(30 \mathrm{mg} \cdot \mathrm{kg}^{-1}\right)$. Concentration of the As $\left(10 \mathrm{mg} \cdot \mathrm{kg}^{-1}\right)$ and $\mathrm{Co}\left(15 \mathrm{mg} \cdot \mathrm{kg}^{-1}\right)$ were about two thirds of the limit values (the data in brackets correspond to the " $\mathrm{A}$ " limits). The coefficient of variation $(\mathrm{CV})$ provides information about the value of the relative standard deviation expressed in the percentage of average. Table 1 shows that the CV value of the Cd was extremely high (105\%), which is associated to a 13.3 skewness value. These values indicate that the distribution of Cd differs from its normal distribution. The $\mathrm{CV}$ value of $\mathrm{B}, \mathrm{Cu}$ and $\mathrm{Pb}$ was quite significant, unlike the $\mathrm{CV}$ values of the $\mathrm{Zn}, \mathrm{Co}, \mathrm{Cr}$, and $\mathrm{Ni}$, which were the lowest, and their skewness values were less than 1 . The distribution of these elements ( $\mathrm{Zn}, \mathrm{Co}, \mathrm{Cr}$, and $\mathrm{Ni}$ ) complied with the terms of normal distribution.

Our results correspond with evaluation of Kuti (2009) who studied the content of PTEs by their median values.

\section{Soil parameters evaluated with $P C A$}

The adequacy test of soil properties shows that the dataset is adequate for PCA. We are unable to show the correlation matrix due to its large size; however, we have concluded that there is correlation among the variables; there were a significant $130(85 \%)$ of the 153 correlation values; furthermore the highest correlation value of 0.8 was between clay $\%$ and KA. Outside the diagonal elements of the anti-image covariance matrix the portion of variance is independent of other variables; therefore these values should be low. In our case less than the quarter of these values were higher than 0.09 that corresponds to the criteria (Sajtos and Mitev 2007). The main diagonal elements of the anti-image correlation matrix are adequate to the expected measures of sampling adequacy (MSA) value. In the case the MSA values have changed between 0.52 and 0.95. The Null hypothesis of Barlett test can be rejected, as the level of significance was less than 0.05 . The KMO value in this example was 0.77 which means that the variables are suitable for PCA.

Table 2 shows the component matrix of the examined parameters and their communality. Communality indicates the amount of common variances of the variables. CEC and pF0 showed the highest communality, and $\mathrm{y} 2$ the lowest. It can be seen (Table 2) that the PC1 group includes the main soil physical properties, where the sand content was in inverse ratio to the remaining variables. The OM's matrix weight values are very close in groups PC1, PC2 and PC4; however its highest value was in PC2 compared to PC1 and PC4. This shows that the soil's organic matter plays an important role in its physical properties, as well as in the creation of negatively charged places, which is correlated slightly with CEC and exchangeable cation contents. The PC3 component consists of soil acidity indication factors, where the y1 and y2 parameters (acidity values) show an inverse relationship with $\mathrm{pH}\left(\mathrm{H}_{2} \mathrm{O}\right)$ and $\mathrm{pH}(\mathrm{KCl})$. The PC4 (BD and pF0) equally indicates the soil compaction and soil structure, and accordingly the extent of hydraulic conductivity of the soil or the rate of infiltration as 
well. The PC5 group consists of salinity parameters such as total salt content (TSC) and soda-alkalinity. The cumulative $\%$ of variations shows the total explained variance at the bottom of Table 2 . This means that five components explain $81.12 \%$ of common variances among all variables. Components 1,2 , and 3 show the highest weight of the explained variances $(24.89 \%, 17.59 \%$ and $17.26 \%$, respectively) in the component analysis.

Table 2

Rotated component matrix (Meaning of notations provided in the text)

\begin{tabular}{lrrrrrr}
\hline \multirow{2}{*}{ Variables } & \multicolumn{5}{c}{ Components } & \multirow{2}{*}{ Communalities } \\
\cline { 2 - 5 } & PC 1 & PC 2 & PC 3 & PC 4 & \multicolumn{1}{c}{ PC 5 } & \\
\hline Sand (\%) & $\mathbf{- 0 . 9 2 4}$ & -0.205 & 0.024 & -0.085 & -0.017 & 0.904 \\
pF2.5 & $\mathbf{0 . 8 5 0}$ & 0.234 & -0.024 & 0.252 & 0.087 & 0.849 \\
Silt (\%) & $\mathbf{0 . 8 1 7}$ & -0.016 & 0.064 & 0.083 & -0.034 & 0.680 \\
pF4.2 & $\mathbf{0 . 7 5 4}$ & 0.291 & 0.051 & 0.167 & 0.112 & 0.697 \\
KA & $\mathbf{0 . 7 3 6}$ & 0.462 & 0.021 & 0.285 & 0.027 & 0.838 \\
Clay (\%) & $\mathbf{0 . 7 3 2}$ & 0.422 & -0.129 & 0.068 & 0.096 & 0.746 \\
CEC & 0.298 & $\mathbf{0 . 9 0 2}$ & 0.117 & 0.109 & 0.111 & 0.940 \\
ecCa & 0.236 & $\mathbf{0 . 8 6 3}$ & 0.222 & 0.107 & 0.000 & 0.860 \\
ecMg & 0.227 & $\mathbf{0 . 8 0 0}$ & 0.069 & 0.093 & 0.120 & 0.719 \\
OM & 0.435 & $\mathbf{0 . 5 0 3}$ & 0.032 & 0.405 & -0.067 & 0.612 \\
y1 & 0.117 & -0.057 & $-\mathbf{0 . 9 2 5}$ & 0.047 & 0.010 & 0.876 \\
pH (KCl) & -0.085 & 0.150 & $\mathbf{0 . 9 0 9}$ & 0.060 & 0.184 & 0.894 \\
pH (H $\left.{ }_{2} \mathrm{O}\right)$ & 0.035 & 0.183 & $\mathbf{0 . 8 9 1}$ & 0.036 & 0.224 & 0.880 \\
y2 & -0.140 & 0.013 & $\mathbf{- 0 . 7 1 7}$ & 0.083 & 0.087 & 0.549 \\
BD & -0.153 & -0.156 & 0.036 & $-\mathbf{0 . 9 2 2}$ & -0.054 & 0.901 \\
pF0 & 0.334 & 0.124 & -0.032 & $\mathbf{0 . 8 8 3}$ & 0.028 & 0.909 \\
Soda & -0.021 & -0.034 & 0.125 & 0.006 & $\mathbf{0 . 9 3 7}$ & 0.895 \\
TSC & 0.162 & 0.203 & 0.071 & 0.060 & $\mathbf{0 . 8 8 3}$ & 0.856 \\
\hline Eigenvalues & 6.915 & 3.355 & 1.637 & 1.376 & 1.344 & 14.603 \\
Cumulative \% & 24.887 & 42.475 & 59.737 & 71.037 & 81.126 & \\
of variations & & & & & & \\
\hline
\end{tabular}

Extraction method: principal component analysis. Rotation method: Varimax with Kaiser normalization. Rotation converged in 6 iterations. Note: Bold denotes the parameters of a component

Figure 1 shows the scatter matrix plot of the components in rotated space (Table 2) which represents the horizontal and vertical distances of variables among the components in the range between -1 and 1 . Within the component variables their proportional and reverse relationship with each other by their component weight matrix is indicated. Figure 1 shows that the coherent variables are separated in both horizontal and vertical direction, depending on the size of the component matrix weight and direction. Those variables that are close to the edge of the graph have an absolute value of variables approaching the value 1 . 
Relationship between soil properties and potentially toxic element content 259
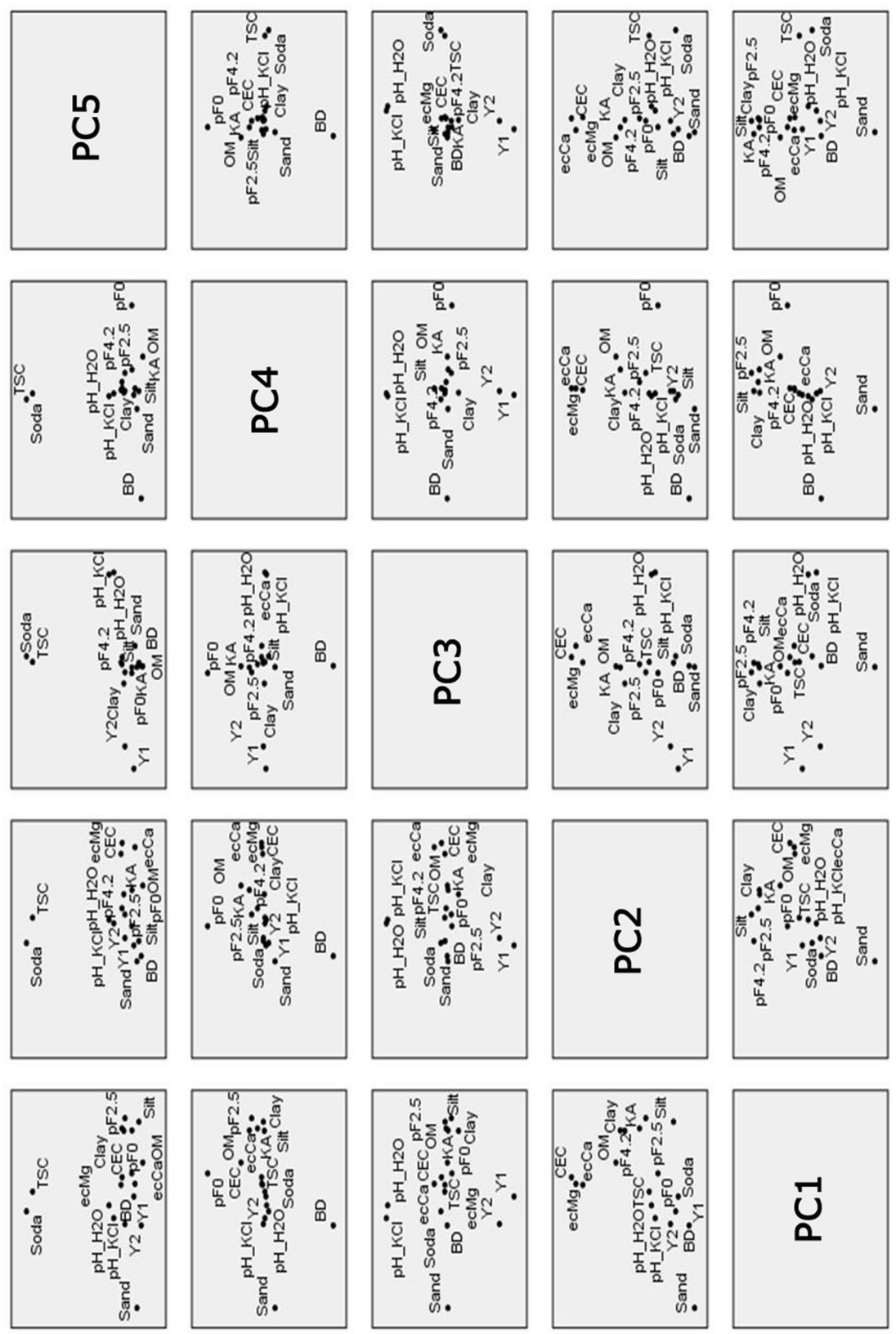

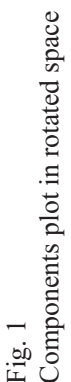


Presentation of correlation between PTE's and groups of the soil parameters

Table 3 shows the possible relationship between PTEs and calculated principal components indicated by Pearson correlation. Arsenic is most closely related to PC2, probably because the sorption reactions on the surfaces of soils influence the mobility, toxicity and availability of arsenic in the subsurface environment (Pigna et al. 2006). However, the correlation is not high $(\mathrm{R}=0.32)$ because PC2 informs mainly about negatively charged surfaces and arsenic is usually present in anionic form as arsenate and arsenite in the soils, and therefore adsorbed in positively charged surfaces by $\mathrm{Fe} / \mathrm{Al}$ oxides (Xu et al. 2009).

Table 3

Correlation between principal components and the PTEs

\begin{tabular}{lccccc}
\hline PTE & PC1 & PC2 & PC3 & PC4 & PC5 \\
\hline As & -0.063 & $0.319^{* *}$ & $0.192^{* *}$ & $-0.151^{* *}$ & -0.022 \\
$\mathrm{~B}$ & 0.024 & $0.366^{* *}$ & $0.206^{* *}$ & 0.048 & $0.215^{* *}$ \\
$\mathrm{Zn}$ & $0.453^{* *}$ & $0.481^{* *}$ & $-0.162^{* *}$ & 0.026 & 0.025 \\
$\mathrm{Cd}$ & $0.335^{* *}$ & $0.143^{* *}$ & -0.069 & $0.109^{* *}$ & -0.054 \\
$\mathrm{Co}$ & $0.467^{* *}$ & $0.427^{* *}$ & $-0.167^{* *}$ & -0.007 & 0.016 \\
$\mathrm{Cr}$ & $0.471^{* *}$ & $0.463^{* *}$ & $-0.134^{* *}$ & $-0.159^{* *}$ & -0.050 \\
$\mathrm{Ni}$ & $0.670^{* *}$ & $0.319^{* *}$ & $-0.177^{* *}$ & $-0.141^{*}$ & $-0.139^{* *}$ \\
$\mathrm{Cu}$ & $0.256^{* *}$ & $0.360^{* *}$ & 0.047 & -0.007 & -0.009 \\
$\mathrm{~Pb}$ & $0.188^{* *}$ & 0.049 & $-0.268^{* *}$ & $0.159^{* *}$ & 0.010 \\
\hline
\end{tabular}

$*, * *$ Correlation is significant at the 0.05 and 0.01 levels, respectively (2-tailed).

The correlation of boron is highest with PC2 $(\mathrm{R}=0.37), \mathrm{PC} 3(\mathrm{R}=0.2)$ and PC5 $(\mathrm{R}=0.215)$, and it is the only one of the examined elements which indicates significant correlation with saline-alkali (PC5) parameters. This observation is explained by the fact that the boron content accumulates better in salty soils of arid areas. The other two components (PC2 and PC3) are also important. This observation is similar to the findings of other authors that boron adsorption is predictable using the soil chemical properties ( $\mathrm{pH}$, soluble salt content, surface area, organic and inorganic carbon content, and aluminum oxide content). Saline-alkali properties (PC5) as well as the amount of the exchangeable cations (PC2) commonly influence the boron mobility in the saline-alkaline soil (Goldberg et al. 2008).

The relationships of $\mathrm{Zn}, \mathrm{Co}, \mathrm{Cr}$ and $\mathrm{Cu}$ are strong with clay, silt and sand fractions, water retention (PC1), CEC, and exchangeable cation (PC2) components. These PTEs are characterized by their mobility that depends mostly on the clay, silt and sand fractions, soil organic matter and CEC, the exchangeable cation contents of the soil. Correlations of $\mathrm{Zn}, \mathrm{Co}$ and $\mathrm{Cr}$ are almost in similar strength with PC1 and PC2. According to the literature the sorption and mobility of these elements is influenced by several factors in soils, such as $\mathrm{pH}$, clay mineral content, CEC and soil organic matter. During the sorption process, metal surface precipitates may also form at the surfaces of phyllo- 
silicate minerals (Shuman 1975; Ford and Sparks 2000; Voegelin et al. 2002; Bradl 2004). The effect of soil $\mathrm{pH}$ on the pseudo total PTE content was weak ( $\mathrm{Zn}, \mathrm{Co}$ and $\mathrm{Cr}$ ) or non-detectable $(\mathrm{Cu})$ in this study.

Similarly, the clay, $\mathrm{CEC}, \mathrm{OM}, \mathrm{pH}$ and $\mathrm{CaCO}_{3}$ contents were the main factors regulating $\mathrm{Ni}$ retention in the studied soils (Mellis et al. 2004; Adhami et al. 2008; Ramachandran and D'Souza 2013). Our study shows that in the case of nickel this relationship is twice stronger with PC1 than with PC2. In our opinion, Ni enriches better in fractions of fine-textured soils.

Cd shows a relatively close correlation with PC1, weak correlation with PC2, PC4 components, and no detectable relation with the $\mathrm{PC} 3$ component. One possible explanation is that the presence of humic substances, mineral components, and proportion of macropores (Camobreco et al. 1996; Bergkvist et al. 2003) regulate the movement (leaching) of cadmium in soil. Our results could not prove the fact that any relationship between $\mathrm{pH}$ (PC3) and $\mathrm{Cd}$ content exists. Likely the effect of $\mathrm{pH}$ prevails in the quantity of $\mathrm{Cd}$ accessible for plants, and not in the pseudo total $\mathrm{Cd}$ content examined by us.

The relationship between $\mathrm{PC} 2$ and $\mathrm{Pb}(\mathrm{R}=0.049)$ was not able to prove that the presence of soil $\mathrm{OM}$ also plays an important role in $\mathrm{Pb}$ adsorption (Pinheiro et al. 1999). It has already been mentioned that the OM's matrix weight values show no significant differences in groups PC1 (0.435), PC2 (0.503) and PC4 (0.405) (see Table 2). Accordingly we assume that the OM content can be a part of group PC1 or PC4 (but not a part of PC2, which has the highest matrix weight); thus the correlation between $\mathrm{OM}$ and $\mathrm{Pb}$ can be detected. The $\mathrm{Pb}$ content in the soil is in significant negative correlation with $\mathrm{PC} 3$, which shows that $\mathrm{Pb}$ solubility and concentration depends on $\mathrm{pH}$ (Elkhatib et al. 1991).

\section{Conclusions}

This article deals with a comparative evaluation of soil properties in their mutual relationship to potential toxic elements. In our study we represented eighteen different variables, which were divided into five major groups by PCA based on their properties, which correspond to accepted professional knowledge. The separated components were the soil physical properties associated with soil texture (PC1), CEC and exchangeable cation contents (PC2), parameters associated with soil acidity (PC3), the variables indicating soil structure and compaction as well as determining fluid flow (hydraulic gradient) (PC4), and alkaline-saline properties (PC5). We found an important relationship between the calculated components and the examined PTEs' concentration in correlation, which are the following:

1. Soil physical variables had no effect on As.

2. There was a weak relationship between the boron concentration and the alkaline-saline variables.

3. CEC and exchangeable cation contents had no effect on $\mathrm{Pb}$; there was only a negative correlation with $\mathrm{pH}$. 
4. The Ni content showed the closest correlation $(\mathrm{R}=0.67)$ with clay, silt and sand fractions, water retention (soil physical parameters); Co behaved very similarly to $\mathrm{Ni}(\mathrm{R}=0.47)$.

5. Zn showed a stronger relationship with CEC and exchangeable cation contents and clay, silt and sand fractions, water retention (soil physical parameters), than $\mathrm{Cd}$ and $\mathrm{Cu}$ did.

We found that the applied method (PCA) was suitable to investigate the effect of different soil parameters on the pseudo total PTEs' concentration. There is a possibility of further development of this method if the analysis of bioavailable content is involved in addition to the pseudo total content of the elements.

\section{References}

Adhami, E., A. Salmanpour, A. Omidi, N. Khosravi, R. Ghasemi-Fasaei, M. Maftoun 2008: Nickel adsorption characteristics of selected soils as related to some soil properties. - Soil Sediment Contamination, 17, pp. 643-653.

Adriano, D.C. 2001: Trace Elements in Terrestrial Environments: Biogeochemistry, Bioavailability and Risks of Metals. 2nd edn. - Springer-Verlag, New York, 871 pp.

Alloway, B.J. 1995: Heavy Metals in Soils. - Chapman \& Hall, London, 368 pp.

Bergkvist, P., N. Jarvis, D. Berggren, K. Carlgren 2003: Long-term effects of sewage sludge applications on soil properties, cadmium availability and distribution in arable soil. - Agriculture, Ecosystems \& Environment, 97, pp. 167-179.

Bradl, H.B. 2004: Adsorption of heavy metal ions of soils and soils constituents. - Journal of Colloid and Interface Science, pp. 277.1-18.

Buzás, I. (Ed.) 1993: Talaj- és agrokémiai vizsgálati módszerkönyv, 1-2 (Methods of Soil Analysis. Parts 1-2). - INDA, Budapest (in Hungarian)

Camobreco, V.J., B.K. Richards, T.S. Steenhuis, L.H. Peverly, M.B. McBride 1996: Movement of heavy metals through undisturbed and homogenized soil columns. - Soil Science, 161, pp. 740-750.

Csathó, P. 1994: Contamination of the environment with heavy metals and its consequences on agricultural production. - RISSAC of the Hungarian Academy of Sciences, $175 \mathrm{pp}$.

Elkhatib, E.A., G.M. Elshebiny, A.M. Balba 1991: Lead sorption in calcareous soils. - Environmental Pollution, 69, pp. 269-276.

Field, A. 2005: Discovering Statistics Using SPSS. - University of Sussex in England, 779 pp.

Fodor, L. 2000: Accumulation of the heavy metals in the soil-plant system. PhD Thesis. Keszthely, Hungary.

Ford, R.G., D.L. Sparks 2000: The nature of Zn precipitates formed in the presence of pyrophyllite. Environmental Science Technology, 34, pp. 2479-2483.

Fügedi, U., I. Horváth, L. Ódor 2006: Geochemical background and environmental pressure of natural origin in surface formations of Hungary. - In: Szendrei, G. (Ed.): Environmental geochemical state of Hungary. Innova Print Kft., Budapest, pp. 11-22.

Goldberg, S., D.L. Suarez, P.J. Shouse 2008: Influence of soil solution salinity on boron adsorption by soils. - Soil Science, 173, pp. 368-374.

Hlavay, J., T. Prohaska, M. Weisz, W.W. Wenzel, G.J. Stingeder 2004: Determination of trace elements bound to soils and sediment fractions. - IUPAC Pure and Applied Chemistry, 76, pp. 415-442.

ISO 11274:1998: Soil quality - Determination of the water retention characteristics - Laboratory methods.

Juhász, I. 2006: Soil conditions in Hungary based on the data from the Soil Conservation Information and Monitoring System (SIMS). - Ministry of Agriculture and Rural Development, Budapest, 90 pp. 
Kádár, I. 1995: The nutrition chain of the soil-plant-animal-human is contaminated with chemical elements in Hungary. - MTA Talajtani és Agrokémiai Kutatóintézete, Budapest.

Kovács, E., Tamás J. 2004: Relationship between heavy metals and vegetation in an abundant mine tailing at Gyöngyösoroszi, Hungary. - In: Phytoremediation: Environmental and Molecular Biological Aspect. OECD Workshop, Mátraháza, Hungary, 70 pp.

Kuti, L. 2009: Agrogeology. - Geological Institute of Hungary, Budapest.

McLean, E.O. 1982: Soil pH and lime requirement. - In: Page, A.L., R.H. Miller, D.R. Keeny (Eds): Methods of Soil Analysis. Part 2. American Society of Agronomy, Inc. Soil Science Society of America, Inc. Madison, WI, USA, pp. 199-224.

Mellis, E.V., M.C. Pessôa da Cruz, J.C. Casagrande 2004: Nickel adsorption by soils in relation to pH, organic matter, and iron oxides. - Scientia Agricola (Piracicaba, Braz.), 61, pp. 190-195.

MSZ-08.0205 1978. MÉM Ágazati Szabvány 1979. A talajfizikai és vízgazdálkodási tulajdonságainak vizsgálata (Investigation of hydrophysical properties of soils). - Budapest. (In Hungarian)

MSZ-21470-50 1998. Környezetvédelmi talajvizsgálatok. Az összes és az oldható toxikus elem-, a nehézfém-, és a króm (VI) tartalom meghatározása (Environmental soil investigation. The total and soluble toxic elements, heavy metal, and chromium (VI) content determination). - Budapest. (In Hungarian)

Navarro, M.C., C. Pérez-Sirvent, M.J. Martínez-Sánchez, J. Vidal, P.J. Tovar, J. Bech 2008: Abandoned mine sites as a source of contamination by heavy metals: A case study in a semi-arid zone. - Journal of Geochemical Exploration, 96, pp. 183-193.

Nelson, R.E. 1982: Carbonate and gypsum. - In: Page, A.L., R.H. Miller, D.R. Keeny (Eds): Methods of Soil Analysis. Part 2. American Society of Agronomy, Inc. Soil Science Society of America, Inc. Madison, WI, USA, pp. 181-197.

Pigna, M., G.S.R. Krishnamurti, A. Violante 2006: Kinetics of arsenate sorption-desorption from metal oxides: Effect of residence time. - Soil Science Society of America Journal, 70, pp. 2017-2027.

Pinheiro, J.P., A.M. Mota, M.F. Benedetti 1999: Lead and calcium binding to fulvic acids: Salt effect and competition. - Environmental Science and Technology, 33, pp. 3398-3404.

Ramachandran, V., S.F. D’Souza 2013: Adsorption of nickel by Indian soils. - Journal of Soil Science and Plant Nutrition, 13, pp. 165-173.

Sajtos, L., A. Mitev 2007: SPSS Research and Data Analyses Handbook. - Alinea, Budapest, 393 pp.

Shuman, L.M. 1975: The effect of soil properties on Zinc adsorption by soils. - Soil Science Society of America Journal, 39, pp. 454-458.

Stefanovits, P. 1999: Soil Science. - Mezőgazda Kiadó, Budapest, 470 pp.

Tyurin, I.V. 1931: A new modification of the volumetric method of determining soil organic matter by means of chromic acid. - Pochvovedenie (in Russian), 26, pp. 36-47.

Várallyay, Gy. 1973: A new apparatus for the determination of soil moisture potential in the low suction range. - Agrokémia és Talajtan, 22, pp. 1-22.

Voegelin, A., A. Scheinost, K. Buhlmann, K. Barmettler, R. Kretzschmar 2002: Slow formation and dissolution of Zn precipitates in soil: A combined column-transport and XAFS study. - Environmental Science Technology, 36, pp. 3749-3754.

Xu, R.K., Y. Wang, D. Tiwari, H. Wang 2009: Effect of ionic strength on adsorption of As(III) and $\mathrm{As}(\mathrm{V})$ on variable charge soils. - Journal of Environmental Science, 21, pp. 927-932.

6/2009 KvVM-EüM-FVM ministerial joint decree limit values to protect geological and groundwater against the pollution. - Magyar Közlöny, 2009(77) (VI.9.) 